\title{
MEREBUT CITRA PEMERINTAH INDONESIA DALAM ON-LINE NEWS \\ (Studi Komparasi Konstruksi Pemberitaan Bencana Kabut Asap di Kompas.Com dan Website Kementerian Kesehatan)
}

\author{
Inri Inggrit Indrayani ${ }^{1 *}$, Yustisia Ditya Sari ${ }^{2}$, Titi Nur Vidyarini ${ }^{3}$ \\ Fakultas Ilmu Komunikasi, Universitas Kristen Petra, Surabaya \\ *Penulis korespondensi; Email: inri.inggrit@petra.ac.id
}

\begin{abstract}
ABSTRAK
Bencana kabut asap yang terjadi di Indonesia pada medio 2015 sebagai akibat kebakaran hutan dan lahan merupakan bencana terbesar yang menarik perhatian media nasional dan asing. Pertama karena cakupan hutan yang terbakar, jumlah korban ISPA serta kerugian materiil yang harus ditanggung pemerintah Indonesia. Penelitian ini dilakukan untuk membandingkan konstruksi pemberitaan yang dilakukan oleh Kompas.com, serta website Kementerian Kesehatan mengenai kasus kabut asap tersebut. Perbandingan ini guna mengetahui bagaimanakah peristiwa yang sama kemudian dilihat berbeda oleh dua organisasi tersebut. Kompas merupakan media cetak nasional yang selama ini memiliki tiras terbesar apabila dibandingkan dengan media cetak lainnya. Sebagai media yang memiliki format depth news, Kompas juga seringkali menjadi referensi bagi perkembangan wacana, ide maupun gagasan yang berhubungan dengan kepentingan masyarakat luas. Website Kementerian Kesehatan merupakan representasi pemerintah Indonesia dalam menangani kasus ini. Metode penelitian yang digunakan dalam penelitian ini adalah framing model Entman yang membagi analisis menjadi empat tahapan yakni Define Problems, Diagnose Causes, Make moral judgement dan Treatment Recommendation. Kompas.com lebih banyak membingkai tentang bencana kabut asap sebagai kelalaian dan kegagalan pemerintah dalam melakukan pengelolaan sumber daya alam. Website Kementerian Kesehatan yang lebih banyak mengupas tentang upaya maksimal serta bantuan medis yang disediakan oleh pemerintah dalam menanggulangi kasus tersebut.
\end{abstract}

Kata kunci: Konstruksi, Membingkai (Framing), Berita, Becana Kabut Asap, 2015, Kompas.com, Website Kementerian Kesehatan.

\begin{abstract}
The haze pollution that occurred in Indonesia in the mid of 2015 as a result of land and forest fires were paid attention, both nasionally and internationally. This research was conducted to compare the framing of the haze news between online media; Kompas.com and the website of Ministry of Health. In this case, the Ministry of Health is an institution that plays a significant role in informing and educating the public as the case gained public attention from both local, national and regional.Furthermore, this study will analyze it with glasses Public Relations (PR). The research method was framing by Entman models which was examined and divided news into four stages, the problem of identification; Causal Interpretation, Moral Evaluation and Treatment Recommendation. The results showed that the case of catastrophic smog impartial framed by Kompas.Com that the government failed to take action pereventif in dealing with the annual disaster. In contrast Strait Time.Com portayed more cornering the government's role in overcoming the disaster at the same inability to provide health insurance for the society at national and regional levels. Ministry of Health intensely proclaimed the government's efforts in handling the haze. In a public relations perspective, the news in the website of the Ministry of Health only doing PR model as a public information rather than an ideal model, two-way symmetrical communication.
\end{abstract}

Keywords: Construction, Framing (Framing), News, Disaster Haze, 2015.

\section{PENDAHULUAN}

Kabut asap yang terjadi di Indonesia pada 2015 merupakan kasus kebakaran hutan yang paling menarik perhatian publik termasuk media. Kasus kabut asap tahun ini bahkan juga menarik perhatian negara lain seperti Malaysia, Singapura, Thailand dan Filipina. Negara jiran tersebut merupakan negara yang terkena imbas dengan adanya bencana kabut asap tersebut. Tidak hanya pemerintahnya saja, media massa di Malaysia dan Singapura bahkan juga konsisten memuat pemberitaan mengenai bencana tersebut. Bahkan dunia internasional juga mempertanyakan mengenai bencana tersebut pada pemerintah Indonesia. Seorang pengamat dari Lowly Institute for International Policy memaparkan bahwa kegagalan 
Indonesia memadamkan kebakaran hutan telah merusak kredibilitasnya. (sumber: news.detik.com). Bencana ini pula yang kemudian menyebabkan Presiden Jokowi harus mempercepat kunjungannya di AS mengingat kritikan keras dari pengamat nasional yang menganggap lemahnya sense of crisis presiden.

Kementerian Kesehatan sebagai institusi terkait dalam kasus ini mendapat perhatian publik oleh karena upaya penanganan mengenai bencana ini dinilai tidak maksimal. Beberapa media massa bahkan secara konsisten melaporkan perkembangan mengenai bencana ini. Penelitian ini kemudian akan melakukan perbandingan atau komparasi konstruksi pemberitaan yang dilakukan oleh Kompas. Kompas merupakan media cetak nasional yang selama ini memiliki tiras terbesar apabila dibandingkan dengan media cetak lainnya. Sebagai media yang memiliki format depth news, Kompas juga seringkali menjadi referensi bagi perkembangan wacana, ide maupun gagasan yang berhubungan dengan kepentingan masyarakat luas.

Dalam Kementerian Kesehatan RI terdapat juga beberapa pemberitaan mengenai kabut asap. Pada penelitian ini, teks-teks Kompas akan digunakan sebagai media pembanding teks-teks yang terdapat dalam oplah terbesar dengan pemberitaan yang dikeluarkan oleh Kementerian Kesehatan mengenai bencana kabut asap.

Kementerian Kesehatan sebagai sebuah organisasi sudah selayaknya membangun understanding kepada publiknya. Salah satu media komunikasi eksternal yang digunakan oleh Kementerian Kesehatan ialah web. Dalam web, pemberitaan mengenai masalah dan aktivitas Kementerian Kesehatan dipublikasikan termasuk penanganan dan kebijakan pemerintah dalam mengangani kasus bencana tersebut.

Sebagai salah satu produk masyarakat modern, media massa merupakan entitas yang signifikan dalam mengkonstruksi realitas sosial. Peter D. Moss (1999) mengungkapkan bahwa wacana media merupakan konstruk kultural yang dihasilkan oleh ideologi oleh karena itu, berita dalam media massa menggunakan frame atau kerangka tertentu untuk memahami realitas sosial.

Rendahl (1995) mengungkapkan bahwa framing telah digunakan untuk memahami dan menginvestigasi komunikasi dan perilaku yang berhubungan dalam disiplin ilmu yang rentangnya luas yang meliputi psikologi, komunikasi lisan (khususnya analisis wacana dan negosiasi), pengambilan keputusan organisasi, komunikasi kesehatan, media studies, dan komunikasi politik.
Penelitian mengenai kabut asap pernah dilakukan oleh Deni Bram dari Fakultas Hukum Universitas Pancasila, Jakarta pada 2012 dengan mengangkat judul Kejahatan Korporasi dalam Pencemaran Lintas Batas Negara: Studi Pencemaran Kabut Asap Kebakaran Hutan di Indonesia. Penelitian tersebut lebih banyak mengkaji bencana kabut asap dari aspek hukum sedangkan belum ada yang melakukan penelitian dari aspek komunikasi. Kesimpulan dalam penelitian Deni Bram ialah pertama, adanya kecenderungan dari lemahnya upaya penegakkan hukum yang terjadi saat ini membuat korporasi beranggapan bahwa kemungkinan mereka mendapatkan sanksi juga lebih kecil. Kedua, diskursus hukum lingkungan di Indonesia saat ini yang masih menempatkan korporasi sebagai subyek hukum hanya dalam tataran normatif belaka semakin memperkecil peluang untuk menghukum dari para pelaku kejahatan lingkungan. Ketiga, kultur masyarakat Indonesia yang belum mampu melakukan penghukuman terhadap brand tertentu melengkapi semakin kecilnya potensi kerugian yang terjadi.

Penelitian ini selanjutnya akan melakukan komparasi pemberitaan mengenai bencana kabut asap nasional yang dimuat oleh media nasional yaitu Kompas.Com; serta website Kementerian Kesehatan Studi mengenai bencana kabut asap dengan melakukan komparasi antara media dengan institusi terkait dalam hal ini Kementerian Kesehatan RI sebagai perwakilan pemerintah belum diungkapkan dalam penelitian. Pemberitaan mengenai kabut asap di website Kementerian Kesehatan RI merupakan representasi bagaimana bencana tersebut dipahami oleh pemerintah sebagai pihak yang berkepentingan serta bagaimana masalah tersebut dipahami oleh para publik.

\section{KAJIAN PUSTAKA}

\subsection{Public Relations dan Citra Organisasi}

Public relations atau relasi publik didefinisikan sebagai sekelompok orang yang mempunyai minat dan kepentingan yang sama, serta menaruh perhatian pada hal yang sama. Sedangkan istilah relations berarti adanya hubungan timbal balik atau two-way-communication, yaitu komunikasi simetris dua arah dalam proses dialog dengan publik untuk mencapai kesepahaman (Bowen, 2000:26).

Frank Jefkins (2003) berusaha merangkai ulang definisi public relations dari definisi yang dikemukakan di atas, yakni sebagai semua bentuk komunikasi yang terencana, baik ke dalam maupun ke luar, antara suatu 
organisasi dengan seluruh khalayaknya dalam rangka mencapai tujuan-tujuan spesifik yang berlandaskan pada saling pengertian. Tujuan-tujuan spesifik tersebut meliputi penyelesaian masalah-masalah komunikasi yang memerlukan perubahan tertentu, misalnya dari sikap negatif menjadi sikap positif. Jefkins juga menambahkan bahwa dalam mencapai tujuan-tujuan tersebut, public relations harus menggunakan management by objectives atau manajemen berdasarkan tujuan, yang artinya semua hasil dan tingkat kemajuan kegiatan public relations harus dapat diukur dengan jelas untuk menentukan tingkat kegagalan atau keberhasilan kegiatan tersebut. Senada dengan Jefkins, Grunig dan Hunt (1984:7) juga telah menegaskan definisi public relations sebagai manajemen komunikasi antara organisasi dengan publiknya (dalam Rhee, 2004:1).

Edward Bernays, salah satu Pioneers Public Relations di tahun 1891-1995, mengemukakan bahwa Public Relations merupakan "good work understood by the public". Bernays menjelaskan dalam peranannya, Public Relations harus memiliki dua formula yang terpenting.

First, a company or organization must do good work. It must produce quality product or provide a valuable service; it must have honest and productive relationship with its custmores, employees, and other constituent group; and it must be socially responsible. The second part of of the formula requires letting people know about an organization's good work through various forms of communication, such as the new media, paid advertising, or in house publications.

Menurut Antar Venus dalam bukunya Manajemen Kampanye, kampanye sebagai kegiatan melaui program yang dilakukan Public Relations, merupakan sebagai perwujudan dari tindakan komunikasi yang terencana dan mewujudkan untuk mempengaruhi khalayaknya. Seperti yang kita ketahui bahwa program kampanye dan Public Relations memiliki perbedaan pemahaman, Randy\& Ruth mengungkapkan bahwa kampanye Public Relations merupakan suatu kegiatan yang dilakukan untuk mempengaruhi khalayak serta mewujudkan tindakan dan aksi komunikasi dalam citra dan reputasi perusahaan.

\subsection{Framing Media Massa}

Dalam sejarahnya, media memiliki relasi yang cukup penting dengan kehidupan masyarakat ataupun industri. Relasi ini menunjukkan peran masyarakat dan industri dalam industri media massa yang men- duduki posisi sebagai obyek pemberitaan. Media, dengan demikian, memiliki peran yang penting dalam membentuk imej suatu industri ataupun masyarakatnya. Dalam fungsinya ini, alih-alih sebagai pelanggeng budaya politik tradisional yang bersifat patriarki, media diharapkan dapat menjadi agent of change.

Fenomena partisipasi masyarakat industri dalam tema baru namun tetap menjadi perhatian serius, terutama oleh media. Dalam hal ini, media berfungsi baik sebagai penyampai pesan yang berasal dari luar organisasi media itu sendiri, dan sebagai pengantar pesan yang telah dikonstruksi oleh jurnalis (Mc Nair, 2003:12). Fungsi yang ke dua inilah yang disebut sebagai fungsi advokasi media yang diwujudkan dalam bentuk agenda setter.

Water Lippmann (1922 dalam Griffin, 2003:390) mengemukakan pendapat bahwa media massa menciptakan imej dari peristiwa di dalam alam pikiran kita. Kemudian oleh McCombs dan Shaw mengembangkannya,

"... as laid out by McCombs and Shaw, the agenda setting hypotesis is relatively strightforward one. Specifically, agenda setting is the process whereby the news media lead the publik assigning relative important to various public isssues (Zhu and Blood, 1997). The media agenda influences the publik agenda not only by saying "this issues is important" in an overt way, but by giving more space and time" (Miller, 2001).

Melalui pendekatan konstruktivis, agenda seting dapat dimaknai sebagai subyektivitas media sebagai organisasi untuk menghadirkan realitas dalam pemberitaannya. Menurut pandangan ini, realitas atau fakta bukan sesuatu yang taken for granted melainkan merupakan konstruksi. Jika pandangan ini dikaitkan kembali dengan sifat media sebagai agenda setter maka, seperti yang ditulis Eriyanto (2002: 22), media dapat juga dimaknai sebagai agen konstruksi.

Apabila media menjadi agen konstruksi, maka produk dari media, yakni pesan itu sendiri seyogyanya merupakan seperangkat kemasan interpretif yang memberi makna kepada suatu isu seperti yang diungkapkan Gamson dan Modigliani (Eriyanto, 202: xvi). Kemasan ini memiliki gagasan atau kerangka (frame) yang mengisyaratkan suatu rentang pandangan. Framing atau pembingkaian melihat bagaimana pesan atau peristiwa atau realitas dikonstruksi oleh media dan disajikan kepada khalayak pembaca.

Ada beberapa pandangan mengenai framing. Menurut Murray Edelman, framing melakukan 
penseleksian realitas yang secara otomatis mendikte khalayak untuk memahami realitas dengan cara tertentu atau dengan bingkai tertentu (Eriyanto, 2002: 156). Perangkat yang digunakan Edelman dalam analisis framing adalah konsep kategorisasi. Kategori, menurut Edelman, membantu manusia untuk memahami realitas yang beragam dan tidak beraturan menjadi realitas yang memiliki makna. Ahli framing lainnya, Robert N. Entman memberikan alternatif perangkat lain yang dapat digunakan untuk melakukan analisis framing, yakni seleksi isu dan penekanan atau penonjolan aspek-aspek tertentu dari realitas atau isu.

\section{METODE}

Peneliti menggunakan analisis framing oleh Entman, secara garis besar analisis tersebut tergambar dalam tabel 1 .

Tabel 1. Model framing Robert N. Entman

\begin{tabular}{ll}
\hline $\begin{array}{l}\text { Define Problems } \\
\text { (Pendefinisian masalah) }\end{array}$ & Bagaimana suatu \\
& peristiwa/isu dilihat ? \\
& Sebagai apa ? Atau sebagai \\
& masaah apa ? \\
\hline Diagnose Causes & Peristiwa itu dilihat \\
(Memperkirakan masalah & disebabkan oleh apa? Apa \\
atau sumber masalah) & yang dianggap sebagai \\
& penyebab dari suatu masalah \\
& ? Siapa (actor) yang \\
& dianggap sebagai penyebab \\
& masalah? \\
\hline Make moral judgement & Nilai moral apa yang \\
(Membuat keputusan moral) & disajikan untuk menjelaskan \\
& masalah ? Nilai moral apa \\
& yang dipakai untuk \\
& melegitimasi atau \\
& mendelegitimasi suatu \\
& tindakan? \\
\hline Treatment Recommendation & Penyelesaian apa yang \\
(Menekankan penyelesaian) & ditawarkan untuk mengatasi \\
& masalah/isu ? Jalan apa yang \\
& ditawarkan dan harus \\
& ditempuh untuk mengatasi \\
& masalah? \\
\hline & \\
\hline
\end{tabular}

\section{TEMUAN DATA DAN ANALISIS}

Berikut merupkan frame Kompas.com

\subsection{Frame: Kondisi kabut asap yang semakin memburuk di daerah-daerah tertentu di Indonesia}

\begin{tabular}{ll}
\hline Problem Identification & $\begin{array}{l}\text { Situasi kota Riau yang } \\
\text { memburuk dalam dua hari } \\
\text { terakhir }\end{array}$ \\
\hline Causal Interpretation & $\begin{array}{l}\text { Memburuknya kondisi } \\
\text { udara Riau disebabkan oleh }\end{array}$ \\
\hline
\end{tabular}

\begin{tabular}{ll}
\hline & $\begin{array}{l}\text { parahnya kabut asap di } \\
\text { wilayah sekitar }\end{array}$ \\
\hline Moral Evaluation & Belum adanya penanganan \\
& yang komprehensif \\
& terhadap bencana kabut \\
& asap sehingga daerah rawan \\
& kabut asap mengalami \\
& kondisi yang semakin \\
& terpuruk \\
\hline Treatment & Penanganan kabut asap \\
Recommendation & jangka pendek perlu \\
& dilakukan seperti \\
& penyiraman hutan dengan \\
& helicopter \\
\hline
\end{tabular}

\section{Problem Identification}

\begin{tabular}{lll}
\hline Judul & Isi Berital & Sumber Berita \\
& Wawancara & \\
\hline Kabut Asap di & Badan & Kepala BMKG \\
Riau Makin & Meteorologi, & Stasiun Pekanbaru, \\
Memburuk & Klimatologi, & Sugarin \\
& dan Geofisika & \\
& Stasiun & Kepala Badan \\
& Pekanbaru & Penanggulangan \\
& menyatakan, & Bencana Daerah \\
& kabut asap & Riau Edwar Sanger \\
& dampak & \\
& kebakaran hutan & \\
& serta lahan yang & \\
& melanda Riau & \\
& terus memburuk & \\
\hline
\end{tabular}

Pada Kompas.com tanggal 27 September ini, pemberitaan yang diangkat ialah mengenai kabut asap di Riau yang semakin memburuk. Pemberitaan ini secara tersirat menunjukkan bahwa belum ada penangangan yang signifikan dalam mengatasi bencana kabut asap. Bahkan kota-kota maupun daerah yang terkena kabut asap saling memperburuk kondisi daerah sekitarnya. Memburuknya kabut asap tersebut berimplikasi pada resiko yang dihadapi pengendara karena jarak pandang yang pendek dan pada akhirnya berpotensi terjadi kecelakaan.

\section{Causal Interpretation}

Dengan wawancara dengan pejabat terkait setempat, Kompas.com mengangkat penyebab memburuknya kabut asap di Riau. Pemberitaan yang mengangkat tajuk "Kabut Asap di Riau Makin Memburuk" menyiratkan bahwa belum melakukan penanganan yang progresif dalam bencana ini. Upaya yang dilakukan pemerintah belum bersifat komprehensif. Berikut adalah kutipan dari Kepala BMKG yang ditulis oleh Kompas.com, 
"Saat ini kabut asap yang terpantau semakin tebal, akibatnya sejumlah daerah seperti Kota Pekanbaru dan Rengat Kabupaten Indragiri Hulu jarak pandang hanya 100 meter," kata Kepala BMKG Stasiun Pekanbaru, Sugarin di Pekanbaru, Minggu (27/9/2015), seperti dikutip Antara.

Kompas.com juga melansir penyebab lain pekatnya kabut asap di Riau yakni kiriman asap yang berasal dari daerah lain. Titik-titik asap di sejumlah daerah belum dipadamkan dengan benar sehingga tidak saja merugikan masyarakat daerah tersebut namun juga menyebabkan semakin buruknya kabut asap di daerah lain. Secara tegas, Kompas.com mengutip pernyataan Kepala Badan Penanggulangan Bencana Riau,

Kepala Badan Penanggulangan Bencana Daerah Riau Edwar Sanger menyatakan bahwa pekatnya kabut asap di Riau merupakan asap kiriman dari provinsi tetangga seperti Sumatera Selatan dan Jambi.

\section{Moral Evaluation}

Dalam pemberitaan yang mengangkat tentang memburuknya kondisi kabut asap di Riau, bingkai Kompas.com menyiratkan bahwa belum adanya upaya strategis pemerintah dalam menangani bencana tersebut. Pemerintah belum proaktif, tidak memikirkan kemungkinan-kemungkinan yang berpotensi terjadi dalam bencana kabut asap padahal peristiwa ini merupakan bencana tahunan. Penanganan kabut asap belum komprehensif sehingga daerah rawan kabut asap mengalami kondisi yang semakin terpuruk.

\section{Treatment Recommendation}

Penanganan kabut asap jangka pendek perlu dilakukan seperti penyiraman hutan dengan helicopter.

\subsection{Frame: Dampak kabut asap bagi kesehatan}

\begin{tabular}{ll}
\hline $\begin{array}{l}\text { Problem } \\
\text { Identification }\end{array}$ & $\begin{array}{l}\text { Kabut asap tidak hanya merusak } \\
\text { lingkungan namun juga kesehat- } \\
\text { an }\end{array}$ \\
\hline $\begin{array}{l}\text { Causal } \\
\text { Interpretation }\end{array}$ & $\begin{array}{l}\text { Kabut asap yang terjadi berlarut- } \\
\text { larut dan berkembang menjadi } \\
\text { kondisi yang membahayakan ke- } \\
\text { sehatan manusia }\end{array}$ \\
\hline Moral Evaluation & $\begin{array}{l}\text { Pemerintah mengabaikan dam- } \\
\text { pak krusial bencana kabut asap } \\
\text { bagi kesehatan }\end{array}$ \\
\hline Treatment & $\begin{array}{l}\text { Menggunakan masker dan gaya } \\
\text { Recommendation } \\
\text { hidup yang sehat }\end{array}$ \\
\hline
\end{tabular}

\section{Problem Identification}

\begin{tabular}{lll}
\hline Judul & Isi Berita/Wawancara & Sumber Berita \\
\hline Bahaya & Gangguan kesehatan & Guru Besar \\
Kabut & akan lebih mudah & Pulmonologi dan \\
Asap Bagi & terjadi pada orang & llmu Kedokteran \\
Kesehatan & yang gangguan paru & Respirasi FKUI \\
& dan jantung, lansia, & sekaligus Kepala \\
& dan anak-anak. & Badan Penelitian \\
& Kabut asap dapat & dan \\
& menyebabkan iritasi & Pengembangan \\
& lokal pada selaput & Kesehatan \\
& lendir di hidung, & (Balitbangkes) \\
& mulut dan & Kementerian \\
& tenggorokan, juga & Kesehatan RI \\
& menyebabkan reaksi & Tjandra Yoga \\
& alergi, peradangan, & Aditama \\
& hingga infeksi saluran & \\
& pernapasan akut & \\
& (ISPA) dan yang & \\
& paling berat menjadi & \\
pneumonia & \\
\hline
\end{tabular}

Dalam pemberitaan tanggal 7 September 2015, Kompas.com mengangkat tajuk "Bahaya Kabut Asap bagi kesehatan" yang menjelaskan dampak berbahaya kabut asap bagi kesehatan manusia. Kabut asap akan menyebabkan gangguan kesehatan pada orang dengan masalah paru dan jantung, lansia, dan anakanak. Kabut asap dapat menyebabkan iritasi lokal pada selaput lendir di hidung, mulut dan tenggorokan, juga menyebabkan reaksi alergi, peradangan, hingga infeksi saluran pernapasan akut (ISPA) dan yang paling berat menjadi pneumonia.

\section{Causal Interpretation}

Kabut asap yang terjadi berlarut-larut dan berkembang menjadi kondisi yang membahayakan kesehatan manusia. Kompas.com mengangkat Guru Besar Pulmonologi dan Ilmu Kedokteran Respirasi FKUI sekaligus Kepala Badan Penelitian dan Pengembangan Kesehatan (Balitbangkes) Kementerian Kesehatan RI Tjandra Yoga Aditama sebagai narasumber dalam pembingkaian ini. Pemilihan narasumber ini sebagai penegasan atas konstruksi bahwa kabut asap secara jangka panjang bukan hanya merugikan lingkungan namun juga membahayakan kesehatan manusia.

"Kemampuan paru dan saluran pernapasan mengatasi infeksi juga berkurang sehingga menyebabkan lebih mudah terjadi infeksi," jelas Tjandra. Tjandra menjelaskan, ISPA pun akan lebih mudah terjadi karena ketidakseimbangan daya tahan tubuh, pola bakteri atau virus, ditambah buruknya lingkungan. 


\section{Moral Evaluation}

Dalam pemberitaan tersebut, Kompas.com membingkai khusus mengenai dampak kabut asap bagi kesehatan. Pembingkaian ini menyiratkan bahwa pemerintah mengabaikan atau lalai terhadap dampak krusial bencana kabut asap bagi kesehatan masyarakat. Dampak ini bersifat jangka panjang dan mematikan. Ketidakwaspadaan mengenai efek ini akan merugikan negara dalam jangka panjang.

\section{Treatment Recommendation}

Rekomendasi yang diajukan oleh Kompas.com dikutip dari Tjandra Yoga yang menyarankan agar masyarakat mengurangi intensitas ke luar rumah, selalu menggunakan masker yang baik jika berada di luar rumah. Lalu, jangan lupa untuk menerapkan pola hidup bersih dan sehat.

\subsection{Frame: Protes Negeri Jiran terkait bencana kabut asap}

\begin{tabular}{ll}
\hline Problem Identification & $\begin{array}{l}\text { Pemerintah Singapura } \\
\text { mengecam sikap pemerintah } \\
\text { Indonesia atas terjadinya } \\
\text { kabut asap yang telah } \\
\text { merusak polusi mereka. }\end{array}$ \\
\hline Causal Interpretation & $\begin{array}{l}\text { Sikap pejabat Indonesia yang } \\
\text { dinilai tidak bertanggung }\end{array}$ \\
& jawab dalam bencana kabut \\
& asap tersebut. \\
\hline Moral Evaluation & $\begin{array}{l}\text { Pemerintah Indonesia tidak } \\
\text { memiliki etika dalam }\end{array}$ \\
& menjalin hubungan \\
& bertetangga yang baik. \\
\hline Treatment & $\begin{array}{l}\text { Pemerintah Indonesia } \\
\text { Recommendation } \\
\text { dengan koordinasi }\end{array}$ \\
& untuk menerintah Singapura \\
& kejahatan korporasian dibalik \\
& kebakaran hutan dan bencana \\
& kabut asap. \\
\hline
\end{tabular}

\section{Problem Identification}

\begin{tabular}{lll}
\hline \multicolumn{1}{c}{ Judul } & \multicolumn{1}{c}{ Isi } & Sumber Berita \\
& \multicolumn{1}{c}{ Berita/Wawancara } & \\
\hline Singapura & Pemerintah Singa- & 1. Menteri Luar \\
Kecam & pura mengecam & Negeri \\
Pejabat & pernyataan pejabat & Singapura K \\
Indonesia & Indonesia terkait & Shanmugam \\
soal Kabut & dengan kabut asap & 2. Wakil \\
Asap & yang juga dialami & Presiden Jusuf \\
\hline
\end{tabular}

\begin{tabular}{ll}
\hline oleh Singapura. & Kalla \\
Pemerintah & 3. Ari \\
Singapura bahkan & Dwipayana \\
menawarkan & dari Tim \\
bantuan kepada & Komunikasi \\
Indonesia untuk & Presiden Joko \\
memadamkan api & Widodo \\
serta koordinasi & 4. Perdana \\
dengan mereka & Menteri \\
mengenai identitas & Singapura Lee \\
perusahaan yang & Hsien Loong \\
bertanggung jawab & \\
dalam & \\
menyebabkan & \\
kebakaran. & \\
\hline
\end{tabular}

Pada tanggal 25 September 2015, Kompas.com mengangkat tajuk "Singapura Kecam Pejabat Indonesia soal Kabut Asap". Pemberitaan tersebut membingkai yang kemarahan serta kecaman pemerintah Singapura yang merasa dirugikan dengan adanya kabut asap yang menyebar sampai ke Singapura. Kabut asap telah menyebabkan lumpuhnya aktivitas masyarakat Singapura serta mengancam lingkungan dan kesehatan mereka.

\section{Causal Interpretation}

Sikap pejabat Indonesia yang dinilai tidak bertanggung jawab dalam bencana kabut asap tersebut. PM Singapura menilai bahwa tidak ada etika pejabat Indonesia dalam menyelesaikan masalah kabut asap.

Singapura telah diselimuti kabut asap yang berasal dari pembakaran lahan di Sumatera dan ditiup angin ke negara kota itu selama sekitar tiga minggu terakhir. Kondisi kabut asap kali ini merupakan yang terburuk sejak pertengahan 2013. Krisis kabut asap melanda negara itu hampir setiap tahun saat musim kemarau.

\section{Moral Evaluation}

Masalah kabut asap ini tidak saja merugikan masyarakat setempat namun juga masyarakat dari negeri Jiran. Kemarahan dan kecaman pemerintah Singapura dalam bingkai kompas.com merupakan mannifestasi kekecewaan mereka terhadap pemerintah Indonesia yang dirasakan tidak memiliki etika dalam menjalin hubungan bertetangga yang baik dalam menangani kabut asap. Indonesia dinilai tidak bertanggung jawab dan tidak menjalankan prinsipprinsip diplomasi yang baik dalam mengatasi bencana ini. 
Saat indeks polusi naik, emosi pun ikut naik. Menteri Luar Negeri Singapura K Shanmugam mengecam beberapa pejabat Indonesia yang menurut dia telah membuat komentar tak pantas tentang masalah tersebut.

"(Walau Jakarta mengatakan bahwa pihaknya tengah mengambil langkah-langkah untuk menangani masalah itu), pada saat yang sama, kita mendengar beberapa pernyataan mengejutkan, di level pejabat senior, dari Indonesia, yang tidak memedulikan rakyat kita, dan rakyat mereka sendiri," kata Shanmugam dalam sebuah posting-an di Facebook pada Kamis malam.

"Bagaimana mungkin pejabat senior pemerintahan mengeluarkan pernyataan seperti itu, tanpa memedulikan rakyat mereka sendiri, atau kita, dan tanpa rasa malu atau rasa tanggung jawab?" kata dia.

\section{Treatment Recommendation}

Pemerintah Indonesia melakukan koordinasi dengan pemerintah Singapura untuk mengungkapkan kejahatan korporasi di balik kebakaran hutan dan bencana kabut asap.

Lee mengatakan, Singapura telah menawarkan bantuan kepada Indonesia untuk memadamkan api. "(Kami juga) meminta mereka berbagi soal identitas perusahaan yang bertanggung jawab dalam menyebabkan kebakaran."

Pemerintah Indonesia sebelumnya mengatakan, sejumlah perusahaan yang berbasis di Singapura termasuk di antara mereka yang bertanggung jawab atas kebakaran di Kalimantan dan Sumatera.

\subsection{Frame: Jumlah penderita ISPA meningkat tajam}

\begin{tabular}{ll}
\hline Problem Identification & $\begin{array}{l}\text { Jumlah masyarakat yang } \\
\text { terkena ISPA dari dampak } \\
\text { kebakaran lahan di Riau } \\
\text { meningkat hingga 100 persen. }\end{array}$ \\
\hline Causal Interpretation & $\begin{array}{l}\text { Kadar polusi udara yang } \\
\text { mengalami peningkatan. }\end{array}$ \\
& $\begin{array}{l}\text { Partikulat udara setiap jamnya } \\
\text { rata-rata di atas 300. Padahal, } \\
\text { toleransi untuk udara yang } \\
\text { bersih di bawah 150 }\end{array}$ \\
\hline Moral Evaluation & $\begin{array}{l}\text { Kondisi yang demikian buruk } \\
\text { di Riau bisa dikategorikan }\end{array}$ \\
\hline
\end{tabular}

\begin{tabular}{ll}
\hline & sebagai kejahatan \\
& kemanusiaan. \\
\hline Treatment & Ada komitmen dari \\
Recommendation & pemerintah untuk \\
& memberikan layanan \\
& kesehatan gratis tanpa syarat- \\
& syarat administratif. \\
\hline
\end{tabular}

\section{Problem Identification}

\begin{tabular}{|c|c|c|}
\hline Judul & Isi Berita/ Wawancara & Sumber Berita \\
\hline $\begin{array}{l}\text { Kenaikan } \\
\text { Jumlah } \\
\text { Korban } \\
\text { ISPA karena } \\
\text { Asap di Riau } \\
\text { Mencapai } \\
\text { 100 Persen } \\
\text { Tahun Ini }\end{array}$ & $\begin{array}{l}\text { 1. Peningkatan kadar } \\
\text { polusi udara di Riau } \\
\text { sudah dikategorikan } \\
\text { sebagai jenis } \\
\text { kejahatan } \\
\text { kemanusiaan. } \\
\text { Penyebab kabut } \\
\text { asap tersebut telah } \\
\text { merampas hak } \\
\text { hidup masyarakat } \\
\text { Riau. } \\
\text { Pemerintah bahkan } \\
\text { tidak memiliki } \\
\text { komitmen untuk } \\
\text { memberikan } \\
\text { pelayanan } \\
\text { kesehatan gratis dan } \\
\text { tanpa syarat. } \\
\text { 2. Mengembalikan tata } \\
\text { kelola hutan ke } \\
\text { pemerintah sebagai } \\
\text { pemangku } \\
\text { kewenangan agar } \\
\text { kelak investor- } \\
\text { investor yang } \\
\text { datang bisa } \\
\text { menjamin bahwa } \\
\text { mereka ramah } \\
\text { terhadap lingkungan } \\
\text { dan ramah terhadap } \\
\text { masyarakat }\end{array}$ & $\begin{array}{l}\text { Ketua Serikat } \\
\text { Perempuan } \\
\text { Indonesia Riau, } \\
\text { Helda Khasmy } \\
\text { Anggota DPRD } \\
\text { Provinsi Riau, } \\
\text { Ade Hartuti }\end{array}$ \\
\hline
\end{tabular}

Pada Sabtu tanggal 19 September 2015, Kompas.com mengangkat tajuk "Kenaikan Jumlah Korban ISPA karena Asap di Riau Mencapai 100 Persen Tahun Ini". Dalam pemberitaan ini, Kompas.com melakukan konstruksi mengenai peningkatan korban kabut asap yang terkena penyakit ISPA. Peningkatan jumlah penderita ISPA disebabkan oleh karena pekatnya kabut asap di Riau. Artinya bahwa belum adanya hasil progresif dalam penangangan kabut asap sehingga penderita ISPA tambah melonjak drastis. Berikut kutipan teks dalam Kompas.com, 
Hampir sebulan terpapar kabut asap, hingga 11 September 2015, Dinas Kesehatan Provinsi Riau mencatat sudah 43.386 orang yang terkena infeksi saluran pernapasan akut (ISPA). Angka tersebut hanya yang terdaftar memeriksakan diri ke rumah sakit dan puskesmas. Jumlah masyarakat yang terkena ISPA dari dampak kebakaran lahan di Riau meningkat hingga 100 persen.

\section{Causal Interpretation}

Pemberitaan pada 19 September 2015 ini menunjukkan bahwa kabut asap yang

"Untuk kadar polusi udara, partikulat udara setiap jamnya rata-rata di atas 300. Padahal, toleransi untuk udara yang bersih di bawah 150," kata Ketua Serikat Perempuan Indonesia Riau Helda Khasmy saat menyampaikan pengaduan asap di Provinsi Riau ke Komisi Nasional Hak Asasi Manusia (Komnas HAM) di Jakarta, Jumat (18/9/2015).

Bahkan, angka konsentrasi partikulat udara bisa mencapai 600 hingga 750. Misalnya, pada 13 September lalu, partikulat udara mencapai 750.

\section{Moral Evaluation}

Dalam kondisi yang berlarut-larut, kabut asap dibingkai sebagai pelanggaran terhadap HAM. Masyakarat yang terpapar kabut asap berpotensi terkena penyakit ISPA akut dan dalam jangka panjang akan menyebabkan kanker. Pemerintah dalam hal ini dianggap lalai atau mengabaikan dampak kabut asap yang berkepanjangan bagi kesehatan manusia.

Helda menekankan, permasalahan ini sudah masuk pada jenis kejahatan kemanusiaan. Sebab, menurut analisis dokter, rata-rata masyarakat Riau yang terkena paparan asap berpotensi terkena kanker paru-paru pada 15 hingga 20 tahun ke depan. Begitu juga pada ibu hamil. Dampak asap bisa melahirkan anak down syndrome.

Selain dampak pada kesehatan, kabut asap juga merugikan masyarakat secara materiil. Akibat kabut asap yang berkepanjangan maka aktivitas perekonomian masyarakat tidak dapat berjalan seperti biasanya.

Menurut dia, beberapa dampak buruk dirasakan masyarakat Riau akibat kabut asap, di antaranya adalah ketidakpastian pendidikan karena sekolah telah berminggu-minggu ditutup serta lumpuhnya ekonomi, khususnya ekonomi menengah.

\section{Treatment Recommendation}

Pemberitaan Kompas.com pada 19 September 2015 ini setidaknya memberikan dua Treatment Recommendation mengenai bencana kabut asap yaitu memberikan pengobatan gratis tanpa syarat dan mengembalikan pengelolaan hutan kepada pemerintah.

Selain itu, Helda menambahkan sudah ada komitmen dari pemerintah untuk memberikan layanan kesehatan gratis. Namun, pada faktanya, masih ada yang diminta untuk mengurus sejumlah surat. Padahal, pada situasi darurat seperti sekarang, idealnya masyarakat diberi layanan kesehatan gratis tanpa syarat.

"Kami berharap tata kelola hutan dapat dikelola kembali oleh pemerintah kabupaten kota, provinsi, dan pusat sebagai pemangku kewenangan agar kelak investor-investor yang datang bisa menjamin bahwa mereka ramah terhadap lingkungan dan ramah terhadap masyarakat sehingga hak masyarakat untuk mendapatkan hidup dengan udara yang bersih tidak tercabut seperti saat ini," kata Ade.

4.5 Di bawah ini adalah frame pemberitaan kabut asap dalam website Kementerian Kesehatan (www.depkes.go.id)

\subsubsection{Frame: Upaya Pemerintah Dalam Menang- gulangi Kabut Asap (18 September 2015)}

\begin{tabular}{|c|c|}
\hline $\begin{array}{l}\text { Problem } \\
\text { Identifications }\end{array}$ & $\begin{array}{l}\text { Tanggal } 1 \text { Maret - 13 September } \\
2015 \text { status siaga darurat kabut } \\
\text { asap di Propinsi Riau meningkat } \\
\text { menjadi tanggap darurat sejak } 14 \\
\text { September } 2015\end{array}$ \\
\hline $\begin{array}{l}\text { Causal } \\
\text { Interpretation }\end{array}$ & $\begin{array}{l}\text { Bencana ini disebabkan oleh } \\
\text { kebakaran hutan yang terjadi di } \\
\text { Propinsi Riau, data sampai } \\
\text { dengan tanggal } 17 \text { September, } \\
\text { mengungkapkan bahwa jumlah } \\
\text { penduduk yang menderita } \\
\text { penyakit sebanyak } 31.518 \text { jiwa. } \\
\text { Diantaranya ISPA, iritasi kulit, } \\
\text { iritasi mata serta pneumonia }\end{array}$ \\
\hline Moral Evaluation & $\begin{array}{l}\text { Dampak bencana kabut asap ini } \\
\text { menimbulkan banyak penyakit, } \\
\text { diharapkan masyarakat selalu } \\
\text { waspada dan dihimbau untuk } \\
\text { tidak keluar rumah }\end{array}$ \\
\hline $\begin{array}{l}\text { Treatment } \\
\text { Recommendations }\end{array}$ & $\begin{array}{l}\text { Upaya untuk meminimalisir dari } \\
\text { dampak ini, pemerintah } \\
\text { mengirimkan tim } \\
\text { penanggulangan krisis serta }\end{array}$ \\
\hline
\end{tabular}


mengajak masyarakat untuk tidak keluar rumah bila tidak perlu, selalu memakai masker, cukup minum dan konsumsi buah serta segara berobat jika sakit. Upaya ini juga didukung dengan pemberian alat logistik seperti; masker, paket gizi (MPASI, MPT-Bumil, dan PMT-AS) sebanyak 3 ton, dan obat-obatan.

\section{Problem Identification}

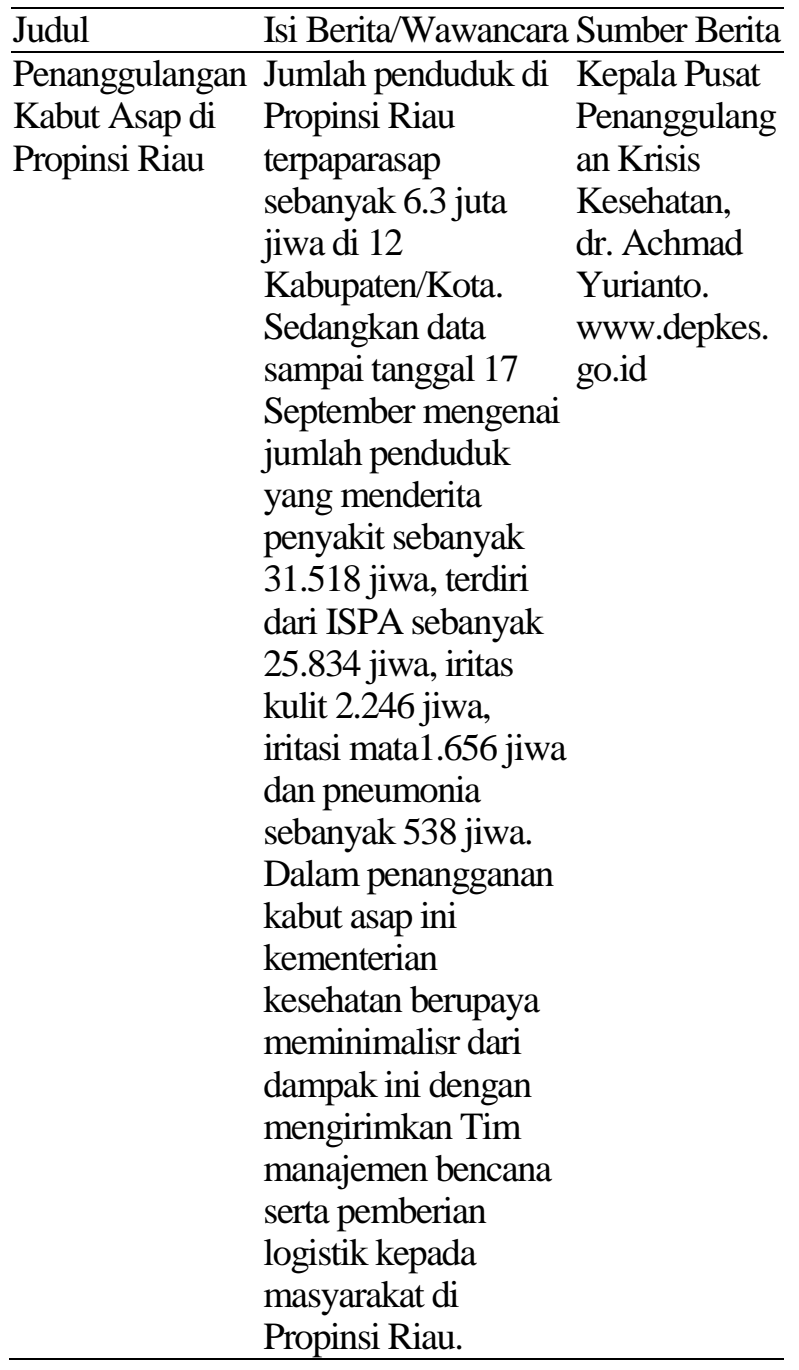

Dalam pemberitaan di media online atau website Kementerian Kesehatan pada tanggal 18 September 2015, peneliti melihat berbagai upaya yang dilakukan oleh pemerintah dalam menanggulangi kabut asap salah satunya adalah menginformasikan kepada masyarakat di propinsi Riau bahwa sejak 14 September 2015, pemerintah menyatakan status siaga darurat kabut asap meningkat menjadi tanggap darurat. Hal ini dikarenakan jumlah penduduk di Propinsi Riau semakin banyak yang menderita penyakit ISPA, iritasi kulit, iritasi mata dan pneumonia, pernyataan ini diperjelas oleh Kepala Pusat Penanggulangan Krisis Kesehatan yang di release melalui pemberitaan yakni;

"Jumlah penduduk di Propinsi Riau terpapar asap sebanyak 6.3 juta jiwa di 12 Kabupaten/ Kota. Sedangkan data sampai tanggal 17 September mengenai jumlah penduduk yang menderita penyakit sebanyak 31.518 jiwa, terdiri dari ISPA sebanyak 25.834 jiwa, iritas kulit 2.246 jiwa, iritasi matal.656 jiwa dan pneumonia sebanyak 538 jiwa. Dalam penangganan kabut asap ini kementerian kesehatan berupaya meminimalisr dari dampak ini dengan mengirimkan Tim manajemen bencana serta pemberian logistik kepada masyarakat di Propinsi Riau".

Pernyataan yang dikemukakan oleh dr. Achmad Yurianto melalui pemberitaan di media website ini menjelaskan bahwa jumlah penduduk di Propinsi Riau semakin meningkat yang terpapar kabut asap, upaya yang dilakukan untuk meminimalisir dari dampak ini pemerintah mengirimkan tim manajemen bencana serta pemberian logistik.

\section{Causal Interpretation}

Pemberitaan yang dilansir oleh Kementerian Kesehatan melalui websitenya pada 18 September 2015 ini, salah satu penyebab bencana ini adalah kebakaran hutan. Kebakaran hutan yang terjadi di Propinsi Riau menyebabkan jumlah penduduk mengalami beberapa penyakit. Berikut pernyataan yang dikemukakan oleh Kementerian Kesehatan melalui Release beritanya;

"Bencana ini disebabkan oleh kebakaran hutan yang terjadi di Propinsi Riau, data sampai dengan tanggal 17 September, mengungkapkan bahwa jumlah penduduk yang menderita penyakit sebanyak 31.518 jiwa. Diantaranya ISPA, iritasi kulit, iritasi mata serta pneumonia"

\section{Moral Evaluation}

Pemerintah terus berupaya menanggulangi kebakaran kabut asap di Propinsi Riau, dengan harapan dengan adanya bencana kabut asap ini, korban yang terkena paparan kabut asap ini semakin berkurang. Salah satu upayan yang dilakukan oleh pemerintah ini berupa ajakan untuk selalu waspada, berikut paparan dari Kementerian Kesehatan melalui wesbitenya pada 18 September 2015;

"Dampak bencana kabut asap ini menimbulkan banyak penyakit, diharapkan masyarakat selalu waspada dan dihimbau untuk tidak keluar rumah". 


\section{Treatment Recommendation}

Dalam pemberitaan tersebut, Kepala Pusat Penanggulangan Krisis Kesehatan yakni dr. Achmad Yurianto menyatakan terus berupaya untuk menimalisir dari dampak yang disebabkan oleh bencana kebut asap ini, dengan cara mengirimkan beberapa tenaga kesehatan, obat-obatan dan logistik bagi korban ataupun masyarakat yang terkena paparan kebakaran hutan.

"Upaya untuk meminimalisir dari dampak ini, pemerintah mengirimkan tim penanggulangan krisis serta mengajak masyarakat untuk tidak keluar rumah bila tidak perlu, selalu memakai masker, cukup minum dan konsumsi buah serta segara berobat jika sakit. Upaya ini juga didukung dengan pemberian alat logistik seperti; masker, paket gizi (MP-ASI, MPT-Bumil, dan PMT-AS) sebanyak 3 ton, dan obat-obatan".

\subsubsection{Frame: Pemerintah Memberikan Sejumlah Bantuan untuk Menanggulangi Bencana Kabut Asap (18 September 2016)}

\begin{tabular}{|c|c|}
\hline $\begin{array}{l}\text { Problem } \\
\text { Identifications }\end{array}$ & $\begin{array}{l}\text { Kebakaran hutan yang melanda di } \\
\text { sejumlah daerah diantaranya Riau, } \\
\text { Jambi, Sumatera Selatan, } \\
\text { Kalimantan Tengah, Kalimantan } \\
\text { Barat, Kalimantan Timur dan } \\
\text { Papua memberikan perhatian } \\
\text { khusus dari pemerintah untuk } \\
\text { segera menanggulangi krisis } \\
\text { tersebut. hutan dan lahan gambut } \\
\text { yang terbakar mengakibatkan } \\
\text { krisis kesehatan yang disebabkan } \\
\text { oleh kabut asap. Oleh karena itu } \\
\text { pemerintah turut memberikan } \\
\text { bantuan sebanyak } 3 \text { ton paket gizi } \\
\text { berupa makanan pendamping ASI, } \\
\text { ibu hamil, dan makanan tambahan } \\
\text { anak sekolah, obat-obatan, masker, } \\
\text { tenda pos kesehatan serta tenaga } \\
\text { kesehatan. }\end{array}$ \\
\hline $\begin{array}{l}\text { Causal } \\
\text { Interpretation }\end{array}$ & $\begin{array}{l}\text { Bencana yang disebabkan oleh } \\
\text { kebakaran hutan sejak juli } 2015, \\
\text { menyebabkan krisis kesehatan } \\
\text { yang berakibat penyakit pada } \\
\text { sejumlah warga. Misalnya ISPA } \\
\text { ke RS mencapai } 5 \text { pasien setiap } \\
\text { hari, sedangkan pneumonia } 471 \\
\text { kasus, asma } 977 \text { kasus, serta iritasi } \\
\text { mata meningkat } 23 \%\end{array}$ \\
\hline Moral Evaluati & $\begin{array}{l}\text { Dampak bencana kabut asap ini } \\
\text { menimbulkan banyak penyakit, } \\
\text { diharapkan masyarakat selalu } \\
\text { waspada dan dihimbau untuk tidak } \\
\text { keluar rumah }\end{array}$ \\
\hline
\end{tabular}

\begin{tabular}{ll}
\hline Treatment & Kementrian kesehatan berupaya \\
Recommendations menanggulangi krisis ini dengan \\
melibatkan seluruh instansi \\
kesehatan, fasilitas layanan \\
kesehatan serta mengurangi resiko \\
bencana dan penambahanan \\
obatan-obatan
\end{tabular}

\section{Problem Identification}

\begin{tabular}{lll}
\hline Judul & \multicolumn{2}{l}{ Isi Berita/Wawancara Sumber Berita } \\
\hline Kemenkes & upaya untuk & Menteri \\
Kirim & menanggulangi krisis Kesehatan, Prof. \\
Bantuan & kesehatan ini & dr. Nila F Moelok, \\
Untuk & melibatkan seluruh & Sp.M (K). \\
Tanggulangi instansi kesehatan & www.depkes.go.id \\
Dampak & dan fasilitas & \\
Kesehatan & pelayanan kesehatan \\
Akibat Asap & di wilayah terdampak \\
& melaui upaya \\
& mengurangi resiko, \\
& dengan menambah \\
& jam operasional serta \\
& distribusi masker dan \\
& penambahan obat ke \\
& beberapa wilayah \\
& terdampak. \\
\hline
\end{tabular}

Dalam pemberitaan yang dilansir oleh depkes.go id, tanggal 18 September 2015 dengan judul "Kemenkes Kirim Bantuan Untuk Tanggulangi Dampak Kesehatan Akibat Asap", sangat terlihat bahwa upaya pemerintah untuk menanggulangi bencana ini sangat optimal. Kebakaran hutan yang melanda di sejumlah daerah seperti Riau, Jambi, Sumatera Selatan, Kalimantan Tengah, Kalimantan Barat, Kalimantan Timur dan Papua memberikan perhatian khusus dari pemerintah untuk segera menanggulangi krisis tersebut. Pemberitaan ini diperkuat oleh Menteri Kesehatan, Prof. dr. Nila F Moelok, Sp.M (K) yang menyatakan akan melibatkan seluruh instansi kesehatan dan pemberian fasilitas pelayanan kesehatan di beberapa wilayah yang terkena dampak kabut asap ;

"Upaya untuk menanggulangi krisis kesehatan ini melibatkan seluruh instansi kesehatan dan fasilitas pelayanan kesehatan di wilayah terdampak melaui upaya mengurangi resiko, dengan menambah jam operasional serta distribusi masker dan penambahan obat ke beberapa wilayah terdampak". Sedangkan pemerintah turut memberikan bantuan sebanyak 3 ton paket gizi berupa makanan pendamping ASI, ibu hamil, dan makanan tambahan anak sekolah, obat-obatan, masker, tenda pos kesehatan serta tenaga kesehatan". 
Framing atau bingkai di atas diperkuat dengan pernyataan Prof. dr. Nila F Moelok, Sp.M (K) sebagai wakil dari pemerintah yakni Menteri Kesehatan yang memberikan solusi atau upaya untuk menanggulangi kebakaran hutan, agar tidak mengakibatkan banyak korban yang terkena paparan asap.

\section{Causal Interpretation}

Dalam bingkai pemberitaan depkes.go.id, bencana kabut asap disebabkan oleh kebakaran hutan yang telah lama terjadi, sehingga menyebabkan jatuhnya korban dan menimbulkan berbagai penyakit. Pencapaian korban yang terkena paparan asap ini, dikabarkan meningkat. Tiap harinya terdapat 5 pasien yang berkunjung ke Rumah Sakit dengan menderita ISPA.

"Bencana yang disebabkan oleh kebakaran hutan sejak juli 2015, menyebabkan krisis kesehatan yang berakibat penyakit pada sejumlah warga. Misalnya ISPA ke RS mencapai 5 pasien setiap hari, sedangkan pneumonia 471 kasus, asma 977 kasus, serta iritasi mata meningkat $23 \% "$

\section{Moral Evaluation}

Dengan adanya bencana kabut asap ini, pemerintah terus berupaya untuk menanggulangi agar tidak semakin banyaknya korba yang terkena paparan kabut asap. Dikarenakan kebakaran ini menimbulkan banyak penyakit jika masyarakat tidak waspada dan perhatian pada krisis ini.

"Dampak bencana kabut asap ini menimbulkan banyak penyakit, diharapkan masyarakat selalu waspada dan dihimbau untuk tidak keluar rumah".

\section{Treatment Recommendations}

Upaya yang terus dilakukan oleh kementrian Kesehatan adalah terus memberikan bantuan kepada daerah yang terkena bencana, dengan cara memberikan fasilitas layanan kesehatan serta mengurangi resiko bencana dan pemberian obat-obatan.

"Kementrian kesehatan berupaya menanggulangi krisis ini dengan melibatkan seluruh instansi kesehatan, fasilitas layanan kesehatan serta mengurangi resiko bencana dan penambahanan obatan-obatan".

\section{KESIMPULAN DAN SARAN}

\subsection{Kesimpulan}

Berdasarkan hasil pembingkaian berita mengenai kabut asap dalam dua website di atas, dapat dirumuskan bahwa Kompas.com lebih banyak membingkai tentang bencana kabut asap sebagai kelalaian dan kegagalan pemerintah dalam melakukan pengelolaan sumber daya alam yang kemudian dikembangkan oleh Kompas.com bahwa kegagalan ini menyebabkan dampak jangka panjang terhadap kualitas generasi masa depan. Kompas.com secara konsisten juga menyebutkan jumlah penderita ISPA di beberapa kawasan bencana kabut asap. Frame ini berbeda dengan pemberitaan yang dilakukan oleh website Kementerian Kesehatan yang lebih banyak mengupas tentang upaya maksimal serta bantuan yang disediakan oleh pemerintah.

Frame pemberitaan bencana kabut asap 2015 yang berbeda merupakan cerminan ideologi dan kepentingan dari publik yang dilayani oleh media tersebut. Kompas.com mewakili publik domestik, termasuk masyarakat dampak bencana kabut asap. Sekalipun, ditemukan juga frame Kompas.com yang memberitakan upaya pemerintah namun frame tersebut bisa dilihat sebagai upaya media tersebut untuk memberitakan berita yang berimbang. Dalam menangani pemberitaan kasus bencana tersebut, Kementerian Kesehatan RI cenderung hanya bersikap reaktif, melakukan pemberitaan yang hanya menjaga citra pemerintah saja. Sebaliknya, tidak menjalankan PR yang two way symmetrical communication mengingat frame pemberitaan di web site Kementerian Kesehatan RI karena pemberitaan yang sifatnya sepihak, propagandis dan tidak transparan mengungkapkan upaya preventif pemerintah sebagai pihak yang paling bertanggung jawab dalam masalah kabut asap tersebut.

\subsection{Saran}

Saran praktis dalam penelitian ini ialah, dalam pemberitaan di website Kementerian Kesehatan RI lebih baik mengadopsi model PR two way symmetrical communication. Permasalahan mengenai kabut asap yang dikonstruksi oleh pemerintah tidak bersikap mengkounter atau reaktif terhadap pemberitaan media massa. Sebaliknya, justru bisa menjadi alternatif bagi rekan media untuk menjawab tantangan bersama.

Saran akademis, penelitian ini melakukan pendekatan kualitatif. Terbuka kesempatan bagi peneliti lain untuk mengkaji pemberitaan kabut asap dengan pendekatan kuantitatif.

\section{DAFTAR PUSTAKA}

Bobbit, Randy \& Sullivan, Ruth. 2009. Public Relations Campaign. United State of America: Pearson Inc. 
Botan, Carl \& Hazleton, Vincent. 2006. Public Relations Theory II. New Jersey: Lawrence Erlbaum Associates.

Corcoran, N. (Ed.). 2013. Communication health: Strategies for health promotion (2nd ed.). London: Sage Publications.

Daymon, C., \& Holloway, I., 2011. Qualitative Research Methods in Public Relations and Marketing Communication. New York: Routledge.

Eriyanto. 2002. Analisis Framing: Konstruksi, ideologi, dan politik media. Yogyakarta: LKiS.

Griffin, Emory A. 2006. A First Look at Communications Theory. Cornel University: Mc. Graw-Hill

Heath, Robert L. 2005. Encyclopedia of Public Relations. London: Sage Publication,

Infate, Dominic A. \& Rancer, Andrew. 1993. Building Communication Theory. United States America : Waveland Press, inc.

Jefkins, Frank. 1992. Public Relations. Jakarta: Erlangga.

Moss, P.D. Conflict and Containment in Television News: A Case Study" dalam Mander, M.S.
(1999). Framing Friction. Urbana: University of Illinois Press dalam Eriyanto. 2002. Analisis Framing: Konstruksi, ideologi, dan politik media. Yogyakarta: LKiS

Rendahl, S. (1995). Frame analysis: From interpersonal to mass communication. Paper presented to Central State Communication Association, Indianapolis, IN dalam Hallahan, K. (1999). Seven Models of Framing: Implications for Public Relations. JOURNAL OF PUBLIC RELATIONS RESEARCH, 11(3), 205-242

Venus, Antar, Drs. M. A. Comm. 2009. Manajemen Kampanye. Bandung: Simbiosa Rekatama Media

Zoller, Heather M. 2008. Emerging Prespective In Health Communications: Meaning, Culture, and Power. English : Routledge

http://nasional.kompas.com/read/2015/11/06/122339 71/556.945.Orang.Kena.ISPA.Dampak.Kabut.A sap)

http://www.bbc.com/indonesia/berita_indonesia/2015 /10/151026_indonesia_kabutasap) 